\title{
SOSIALISASI KEBIASAAN BARU PADA IBU HAMIL DALAM PEMERIKSAAN ANC PADA DI MASA PANDEMI COVID 19
}

\author{
Riance Mardiana Ujung ${ }^{1}$, Dimpu Rismawaty Nainggolan ${ }^{2}$ \\ ${ }^{12}$ Prodi DIII Kebidanan Tarutung Poltekkes Kemenkes
}

\section{ARTICLE INFORMATION}

Received: February 00, 00

Revised: March 00, 00

Available online: April 00, 00

\section{KEYWORDS}

Five words maximum, comma separated

\section{CORRESPONDENCE}

Phone: +62 (0751) 12345678

E-mail: first_author@affiliation.xx.xx

\section{A B S T R A K}

Corona virus adalah suatu kelompok virus yang dapat menyebabkan penyakit pada manusia. Covid-19 dapat menyebar terutama dari orang ke orang melalui percikan dari hidung atau mulut yang keluar saat orang yang terinfeksi Covid-19 batuk, bersin atau berbicara. Orang dapat terinfeksi dengan menyentuh benda yang terpercik virus covid19, kemudian menyentuh mata, hidung, atau mulut. Kegiatan Pengabdian Masyarakat ini memiliki tujuan untuk mewujudkan salah satu kegiatan Tri darma Perguruan Tinggi dan meningkatkan pengetahuan dan kedisiplinan ibu hamil tentang kebiasaan baru dalam Pemeriksaan kehamilan pertama kali dibutuhkan untuk skrining faktor risiko, adanya komplikasi penyulit dalam kehamilan, mempelajari buku KIA dan mengisi P4K, tanda bahaya dalam kehamilan, upaya Pencegahan dan cara mengatasi Covid19, menunda Pemeriksaan USG, Kelas ibu hamil, Pemeriksaan kehamilan TM II untuk sementara waktu. Selain itu, tetap menjaga protokol kesehatan yaitu memakai masker, mencuci tangan atau menggunakan handsanitezer, dan menjaga jarak. Hasil dari kegiatan pengabdian masyarakat ini adalah terlaksananya penyuluhan kesehatan yang dihadiri oleh Kepala desa beserta perangkatnya, Bidan Desa, Tim Pengabdi dan Ibu hamil sejumlah 59 orang. Saat pelaksanaan penyuluhan, ibu-ibu hamil bertanya dengan antusias tentang hal-hal yang berkaiatan dengan kebiasaan baru serta dapat mengikuti Simulasi cara membuat Handsanitizer. Setelah pelaksanaan pengabdian masyarakat ini diharapkan ibu hamil menjadi paham tentang pencegahan infeksi COVID-19, prosedur pemeriksaan kehamilan di era pandemi, cara menjaga kesehatan ibu hamil di era pandemi, upaya yang dilakukan ketika ibu hamil sakit di era pandemi sehingga ibu hamil mau memeriksakan kehamilannya selama pandemi COVID-19 dengan menerapkan protocol kesehatan agar pertumbuhan dan perkembangan janin dapat terpantau dengan baik.

Kata Kunci : Sosialisasi, Pemeriksaan ANC, Covid-19

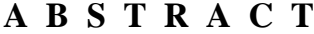

Corona virus is a group of viruses that can cause disease in humans. Covid-19 can spread mainly from person to person through droplets from the nose or mouth that come out when an infected person coughs, sneezes or talks. People can become infected by touching an object that has been splattered with the COVID-19 virus, then touching their eyes, nose or mouth. This Community Service activity has the aim of realizing one of the Tri Dharma activities of Higher Education and increasing knowledge and discipline of pregnant women about new habits in the first pregnancy examination needed to screen for risk factors, the presence of complications in pregnancy, study the $\mathrm{MCH}$ handbook and fill out $\mathrm{P} 4 \mathrm{~K}$, signs dangers in pregnancy, prevention efforts and ways to overcome Covid-19, delaying ultrasound examination, class for pregnant women, TM II pregnancy examination for a while. In addition, maintaining health protocols, namely wearing masks, washing hands or using hand sanitizer, and maintaining distance. The result of this community service activity was the implementation of health counseling which was attended by the village head and his apparatus, the village midwife, the service team and 59 pregnant women. During the counseling, pregnant women asked enthusiastically about things related to new habits and could take part in the Simulation of how to make Handsanitizer. After the implementation of this community service, it is hoped that pregnant women will understand about preventing COVID-19 infection, pregnancy check procedures in the pandemic era, how to maintain the health of pregnant women in the pandemic era, efforts made when pregnant women are sick in the pandemic era so that pregnant women want to have their pregnancy checked during the pandemic. the COVID-19 pandemic by implementing a health protocol so that fetal growth and development can be monitored properly.

Keywords: Socialization, ANC Examination, Covid-19 


\section{Pendahuluan}

Covid-19 adalah penyakit menular yang disebabkan oleh jenis corona virus yang baru ditemukan. Virus baru dan penyakit yang disebabkannya tidak dikenal sebelum mulainya di Kota Wuhan, Tiongkok, bulan Desember 2019. Covid 19 ini sekarang menjadi pandemic yang terjadi di banyak negara (WHO, 2020). Corona virus adalah suatu kelompok virus yang dapat menyebabkan penyakit pada manusia. Beberapa jenis corona virus diketahui menyebabkan infeksi saluran nafas pada manusia mulai dari batuk pilek hingga yang lebih serius seperti Middle East Respiratory Syndrome (MERS) dan Severe Acute Respiratory Syndrome (SARS) (Kemenkes, 2020).

Corona Virus atau Covid-19 telah berdampak meningkatnya jumlah korban dan kerugian harta benda, meluasnya cakupan wilayah yang terkena bencana, serta menimbulkan implikasi pada aspek sosial ekonomi yang luas di Indonesia. Pemerintah telah menetapkan bencana non alam ini sebagai bencana nasional melalui Keputusan Presiden Republik Indonesia Nomor 12 Tahun 2020 tentang Penetapan Bencana Nonalam Penyebaran Corona Virus Disease 2019 (Covid-19) sebagai Bencana Nasional ( Kemenkes, 2020 )

Dalam situasi normal, kematian ibu dan kematian neonatal di Indonesia masih menjadi tantangan besar, apalagi pada saat situasi bencana. Saat ini, Indonesia sedang menghadapi bencana nasional non alam Covid-19 sehingga pelayanan kesehatan maternal dan neonatal menjadi salah satu layanan yang terkena dampak baik secara akses maupun kualitas. Dikhawatirkan, hal ini menyebabkan adanya peningkatan morbiditas dan mortalitas ibu dan bayi baru lahir. Dalam situasi pandemi Covid-19 ini, banyak pembatasan hampir ke semua layanan rutin termasuk pelayanan kesehatan maternal dan neonatal. Seperti ibu hamil menjadi enggan ke puskesmas atau fasiltas pelayanan kesehatan lainnya karena takut tertular, adanya anjuran menunda pemeriksaan kehamilan dan kelas ibu hamil, serta adanya ketidaksiapan layanan dari segi tenaga dan sarana prasarana termasuk Alat Pelindung Diri. Dengan adanya Penyuluhan /Sosialisasi bagi ibu dan keluarga serta tenaga kesehatan dalam memberikan pelayanan ANC, di masa pandemi Covid-19. Diharapkan ibu dan bayi tetap mendapatkan pelayanan esensial, faktor risiko dapat dikenali secara dini, serta mendapatkan akses pertolongan kegawatdaruratan dan tenaga kesehatan mendapatkan perlindungan dari tertular Covid-19 ( Kemenkes , 2020 )

Pemeriksaan kehamilan pertama kali dibutuhkan untuk skrining faktor risiko (termasuk Program Pencegahan Penularan HIV, Sifilis dan Hepatitis B dari ibu ke anak / PPIA). Oleh karena itu, dianjurkan pemeriksaannya dilakukan oleh dokter di fasilitas pelayanan kesehatan dengan perjanjian agar ibu tidak menunggu lama. Apabila ibu hamil datang ke bidan tetap dilakukan pelayanan ANC, kemudian ibu hamil dirujuk untuk pemeriksaan oleh dokter (Kemenkes, 2020 )
Antenatal care untuk wanita hamil yang terkonfirmasi Covid-19 pasca perawatan, kunjungan antenatal selanjutnya dilakukan 14 hari setelah periode penyakit akut berakhir. Periode 14 hari ini dapat dikurangi apabila pasien dinyatakan sembuh. Direkomendasikan dilakukan USG antenatal untuk pengawasan pertumbuhan janin, 14 hari setelah resolusi penyakit akut. Meskipun tidak ada bukti bahwa gangguan pertumbuhan janin (IUGR) akibat Covid-19, didapatkan bahwa duapertiga kehamilan dengan SARS disertai oleh IUGR dan solusio plasenta terjadi pada kasus MERS, sehingga tindak lanjut ultrasonografi diperlukan ( Kemenkes, 2020).

Orang dapat tertular Covid-19 dari orang lain yang terinfeksi virus ini. Covid-19 dapat menyebar terutama dari orang ke orang melalui percikan-percikan dari hidung atau mulut yang keluar saat orang yang terinfeksi Covid-19 batuk, bersin atau berbicara. Percikan-percikan ini relatif berat, perjalanannya tidak jauh dan jatuh ke tanah dengan cepat. Orang dapat terinfeksi Covid-19 jika menghirup percikan orang yang terinfeksi virus ini. Oleh karena itu, penting bagi kita untuk menjaga jarak minimal 1 meter dari orang lain. Percikanpercikan ini dapat menempel di benda dan permukaan lainnya di sekitar orang seperti meja, gagang pintu, dan pegangan tangan. Orang dapat terinfeksi dengan menyentuh benda atau permukaan tersebut, kemudian menyentuh mata, hidung, atau mulut mereka. Inilah sebabnya penting untuk mencuci tangan secara teratur dengan sabun dan air bersih mengalir, atau membersihkannya dengan cairan antiseptik berbahan dasar alkohol ( Johns H. Bloomberg, 2020 )

Penyakit ini belum ada obat/vaksinnya dan sudah menjadi pandemi yang menyebabkan banyak kematian di dunia maupun di Indonesia dan sampai saat ini kasusnya masih terus meningkat. Untuk melawan virus ini hal utama yang perlu kita lakukan adalah melakukan tindakan pencegahan seperti: sering cuci tangan pakai sabun, menerapkan etika batuk/pakai masker, meningkatkan daya tahan tubuh, menjaga jarak dan hindari kerumunan. Intinya harus selalu berperilaku hidup bersih dan sehat (PHBS). Kelihatannya hal ini sepele, tetapi kenyataannya masih cukup banyak yang tidak melakukan hal tersebut.

Kementerian Kesehatan beserta jajarannya di daerah tak henti-hentinya melakukan sosialisasi, edukasi kepada masyarakat agar paham apa yang harus dilakukan supaya terhindar dari Covid-19. Namun, hasilnya masih belum memuaskan karena kasusnya masih terus meningkat. Terbukti kasus pertanggal 18 Juli 2020 di Indonesia bertambah 1752 kasus menjadi 84.882 yang terkonfirmasi positif korona mulai dari bulan maret. Provinsi Sumatera Utara termasuk dalam urutan 8 provinsi tertinggi secara nasional pertambahan Covid 19 dengan jumlah kasus keseluruhan sampai tanggal 18 Juli 2020 sebanyak 2923 kasus. Kabupaten Tapanuli Utara diperoleh data di bulan Mei 4 kasus positif diantaranya 1 orang ibu hamil ( Kemenkes, 2020)

Pada masa pandemi masyarakat Indonesia diharuskan hidup dengan tatanan hidup baru, yang dapat 'berdamai' dengan Covid-19. Adapun yang dimaksud dengan New Normal adalah suatu tindakan atau perilaku yang dilakukan oleh masyarakat dan semua institusi yang ada di wilayah tersebut untuk melakukan pola harian atau pola kerja atau pola hidup baru yang berbeda dengan sebelumnya. Bila hal ini tidak dilakukan, akan terjadi risiko penularan. Tujuan dari New Normal adalah agar masyarakat tetap produktif dan aman dari Covid-19 di masa pandemi. 
"New Normal" dinarasikan menjadi "Adaptasi Kebiasaan Baru". Maksud dari adaptasi kebiasaan baru adalah agar kita bisa bekerja, belajar dan beraktivitas dengan produktif di era Pandemi Covid-19. Hal ini bisa dilakukan kalau kita beradaptasi dengan kebiasaan baru yaitu disiplin hidup sehat dengan menerapkan protokol kesehatan secara ketat ( Kemenkes, 2020)

Kebiasaan baru untuk hidup lebih sehat harus terus menerus dilakukan di masyarakat dan setiap individu, sehingga menjadi normal sosial dan norma individu baru dalam kehidupan sehari hari. Bila kebiasaan baru tidak dilakukan secara disiplin atau hanya dilakukan oleh sekelompok orang saja, maka hal ini bisa menjadi ancaman wabah gelombang kedua. Kebiasaan lama yang sering dilakukan, seperti bersalaman, cipika-cipiki, cium tangan, berkerumun/ bergerombol, malas cuci tangan harus mulai ditinggalkan karena mendukung penularan Covid-19.

Kita dituntut untuk mampu mengadaptasi/ menyesuaikan kebiasaan baru dimanapun kita berada, seperti di rumah, di kantor, di sekolah, di tempat ibadah, dan juga di tempat-tempat umum, seperti terminal, pasar, dan mal. Diharapkan dengan seringnya menerapkan kebiasaan baru dimanapun, semakin mudah dan cepat menjadi normal individu dan norma masyarakat.

Berdasarkan uraian diatas, kami tim Pengabdian masyarakat Program Studi D III Kebidanan Tarutung Poltekkes Kemenkes Medan tertarik untuk melakukan pengabdian masyarakat dengan kegiatan penyuluhan dengan judul "Sosialisasi Kebiasaan Baru Pada Ibu Hamil Dalam Pemeriksaan ANC di Masa Pandemi Covid-19 di Wilayah Kerja Puskesmas Siatas BaritaTahun 2020 “.

Kegiatan Pengabdian Masyarakat ini memiliki beberapa tujuan antara lain :

a. Mewujudkan salah satu kegiatan Tri darma Perguruan Tinggi.

b. Meningkatkan pengetahuan dan kedisiplinan ibu hamil tentang kebiasaan baru dalam pemeriksaan ANC di masa Pandemi Covid 19 di Wilayah kerja Puskesmas Siatas Barita Tahun 2020.

\section{METHOD}

Kegiatan pengabdian masyarakat ini dilakukan pada hari Sabtu, 29 Agustus 2020 dan 12 September 2020 bertempat di Desa Lumban Ratus, Sangkaran, Lumban Siagian dan Pancurnapitu yang termasuk dalam Wilayah kerja Puskesmas Siatas Barita Kabupaten Tapanuli Utara dengan memberikan penyuluhan tentang Sosialisasi kebiasaan baru pada Ibu hamil dalam Pemeriksaan ANC dimasa Pandemi Covid-19 yang dihadiri oleh Kepala desa beserta perangkatnya, Bidan Desa, Tim Pengbadi dan Ibu hamil. Yang menjadi sasaran dalam Kegiatan ini adalah Ibu-ibu hamil yang berjumlah 32 orang. Penyuluhan yang diberikan kepada Ibu hamil berupa Pemeriksaan kehamilan pertama kali dibutuhkan untuk skrining faktor risiko, Adanya komplikasi penyulit dalam kehamilan, Mempelajari buku KIA dan mengisi P4K, Mengenal tanda bahaya dalam kehamilan, upaya Pencegahan dan cara mengatasi Covid-19 Pada Ibu hamil dan memberitahu ibu untuk penundaan Pemeriksaan USG, Kelas ibu hamil, Pemeriksaan kehamilan TM II untuk sementara waktu. Dalam pengabdian ini juga dilakukan Simulasi cara membuat Handsanitizer.

\section{HASIL DAN PEMBAHASAN}

Hasil dari kegiatan pengabdian masyarakat ini adalah terlaksananya penyuluhan kesehatan yang dihadiri oleh Kepala desa beserta perangkatnya, Bidan Desa, Tim Pengabdi dan Ibu hamil sejumlah 59 orang. Penyuluhan yang disampaikan bertujuan untuk merubah kebiasaan ibu hamil dalam memeriksakan kehamilannya yaitu menghubungi tenaga kesehatan terlebih dahulu, memahami buku KIA dan mampu menerapkannya dalam kehidupan, menjalankan protokol kesehatan. Saat pelaksanaan penyuluhan, ibu-ibu hamil bertanya dengan antusias tentang hal-hal yang berkaiatan dengan kebiasaan baru.

Penyuluhan kesehatan adalah kegiatan pendidikan yang dilakukan dengan cara menyebarkan informasi-informasi pesan, menanamkan keyakinan, sehingga masyarakat sadar, tahu dan mengerti, tetapi juga mau dan biasa melakukan suatu anjuran yang ada hubungannya dengan kesehatan serta terjadi peningkatan pengetahuan, keterampilan, dan sikap (Notoatmodjo, 2012).

Penyuluhan yang diberikan adalah mengenai kebiasaan baru pada Ibu hamil dalam Pemeriksaan ANC dimasa Pandemi Covid-19. Pemeriksaan kehamilan pertama kali dibutuhkan untuk skrining faktor risiko (termasuk Program Pencegahan Penularan HIV, Sifilis dan Hepatitis B dari ibu ke anak / PPIA). Oleh karena itu, dianjurkan pemeriksaannya dilakukan oleh dokter di fasilitas pelayanan kesehatan dengan perjanjian agar ibu tidak menunggu lama. Apabila ibu hamil datang ke bidan tetap dilakukan pelayanan ANC, kemudian ibu hamil dirujuk untuk pemeriksaan oleh dokter. Adapun kebiasaan baru pada Ibu hamil dalam Pemeriksaan ANC dimasa Pandemi Covid-19 adalah : Dilakukan anamnesis dan pemeriksaan skrining dan pada daerah endemis malaria, seluruh ibu hamil pada pemeriksaan pertama dilakukan pemeriksaan RDT malaria dan diberikan kelambu berinsektisida; Jika ada komplikasi atau penyulit maka ibu hamil dirujuk untuk pemeriksaan dan tata laksana lebih lanjut; Pemeriksaan rutin (USG) untuk sementara dapat ditunda pada ibu dengan PDP atau terkonfirmasi Covid-19 sampai ada rekomendasi dari episode isolasinya berakhir. Pemantauan selanjutnya dianggap sebagai kasus risiko tinggi; Ibu hamil diminta mempelajari buku KIA untuk diterapkan dalam kehidupan sehari-hari termasuk mengenali tanda bahaya pada kehamilan dan jika ada keluhan atau tanda bahaya, ibu hamil harus segera memeriksakan diri ke fasyankes; Pengisian stiker P4K dipandu bidan/perawat/dokter melalui media komunikasi. Pedoman Bagi Ibu Hamil, Nifas, Bersalin, dan Bayi Baru Lahir di Era Pandemi Covid-19; Kelas Ibu Hamil ditunda pelaksanaannya di masa pandemi Covid-19 atau dapat mengikuti kelas ibu secara online; Tunda pemeriksaan pada kehamilan trimester kedua atau pemeriksaan antenatal dapat dilakukan melalui tele-konsultasi klinis, kecuali dijumpai keluhan atau tanda bahaya; Ibu hamil yang pada kunjungan pertama terdetekdi memiliki faktor risiko atau penyulit harus memeriksakan kehamilannya pada trimester kedua dan jika Ibu tidak datang ke fasyankes, maka tenaga kesehatan melakukan kunjungan rumah untuk melakukan pemeriksaan ANC, pemantauan dan tataksana faktor penyulit atau jika diperlukan lakukan rujukan ibu hamil ke fasyankes untuk mendapatkan pemeriksaan dan tatalaksana lebih lanjut, termasuk pada ibu hamil dengan HIV, Sifilis dan Hepatitis B; Pemeriksaan kehamilan trimester ketiga harus dilakukan dengan tujuan utama untuk menyiapkan proses persalinan dan dilaksanakan 1 bulan sebelum taksiran persalinan; Ibu hamil harus memeriksa kondisi 
ISSN (Online) 2722-1083,

dirinya sendiri dan gerakan janinnya dan jika terdapat risiko/tanda bahaya (tercantum dalam buku KIA), seperti mualmuntah hebat, perdarahan banyak, gerakan janin berkurang, ketuban pecah, nyeri kepala hebat, tekanan darah tinggi, kontraksi berulang, dan kejang. Ibu hamil dengan penyakit diabetes mellitus gestasional, pre eklampsia berat, pertumbuhan janin terhambat, dan ibu hamil dengan penyakit penyerta lainnya atau riwayat obstetri buruk maka periksakan diri ke tenaga kesehatan; Pastikan gerak janin dirasakan mulai usia kehamilan 20 minggu dan setelah usia kehamilan 28 minggu, hitunglah gerakan janin secara mandiri (minimal 10 gerakan per 2 jam); Ibu hamil diharapkan senantiasa menjaga kesehatan dengan mengonsumsi makanan bergizi seimbang, menjaga kebersihan diri dan tetap mempraktikan aktivitas fisik berupa senam ibu hamil/yoga/pilates/peregangan secara mandiri di rumah agar ibu tetap bugar dan sehat; Ibu hamil tetap minum tablet tambah darah sesuai dosis yang diberikan oleh tenaga kesehatan. Pedoman Bagi Ibu Hamil, Nifas, Bersalin, dan Bayi Baru Lahir di Era Pandemi Covid-19; Ibu hamil dengan status PDP atau terkonfirmasi positif Covid-19 tidak diberikan tablet tambah darah karena akan memperburuk komplikasi yang diakibatkan kondisi Covid-19; Antenatal care untuk wanita hamil yang terkonfirmasi Covid-19 pasca perawatan, kunjungan antenatal selanjutnya dilakukan 14 hari setelah periode penyakit akut berakhir karena periode 14 hari ini dapat dikurangi apabila pasien dinyatakan sembuh dan direkomendasikan dilakukan USG antenatal untuk pengawasan pertumbuhan janin, 14 hari setelah resolusi penyakit akut. Meskipun tidak ada bukti bahwa gangguan pertumbuhan janin (IUGR) akibat Covid-19, didapatkan bahwa duapertiga kehamilan dengan SARS disertai oleh IUGR dan solusio plasenta terjadi pada kasus MERS, sehingga tindak lanjut ultrasono grafi diperlukan; Jika ibu hamil datang di rumah sakit dengan gejala memburuk dan diduga / dikonfirmasi terinfeksi Covid-19, berlaku beberapa rekomendasi berikut: Pembentukan tim multi-disiplin idealnya melibatkan konsultan dokter spesialis penyakit infeksi jika tersedia, dokter kandungan, bidan yang bertugas dan dokter anestesi yang bertanggung jawab untuk perawatan pasien sesegera mungkin setelah masuk. Diskusi dan kesimpulannya harus didiskusikan dengan ibu dan keluarga tersebut; Konseling perjalanan untuk ibu hamil, sebaiknya tidak melakukan perjalanan ke luar negeri dengan mengikuti anjuran perjalanan (travel advisory) yang dikeluarkan pemerintah. Dokter harus menanyakan riwayat perjalanan terutama dalam 14 hari terakhir dari daerah dengan penyebaran luas Covid-19.

Kegiatan Pengabdian masyarakat ini juga melakukan Simulasi cara membuat Handsanitizer. Adapun cara membuat hand sanitizer sesuai standar WHO adalah sebagai berikut : Pilih formula hand sanitizer yang Anda inginkan. Lalu masukkan Ethanol (untuk formula 1) atau Isopropil alkohol (untuk formula 2) sesuai takaran ke dalam jerigen; Masukkan cairan hidrogen peroksida ke dalam jerigen sesuai takaran; Masukkan gliserin karena bersifat lengket dan kental dapat juga diganti dengan aloevera ( Lidah buaya) dan Anda bisa menggunakan sedikit air steril untuk membilas gliserin dalam gelas ukur sebelum memasukkannya ke jerigen; Setelah seluruh bahan dimasukkan dalam 1 jerigen, masukkan 1 liter air distilasi dan jangan lupa tutup jerigen agar alkohol tidak menguap; Kocok jerigen secara perlahan agar ketiga bahan tersebut bisa tercampur dengan rata; Tak butuh waktu lama, hand sanitizer pun siap dipindahkan ke botol-botol yang lebih kecil agar mudah dibawa; Terakhir, simpan botol-botol ini selama 72 jam (kurang lebih 3 hari) untuk menghindari kontaminasi dari botol; Hand sanitizer sudah siap dibawa dan digunakan.

Hal ini perlu diketahui oleh ibu hamil agar terhindar dari Covid19. Selain itu, tetap menjaga protokol kesehatan yaitu memakai masker, mencuci tangan atau menggunakan handsanitezer, dan menjaga jarak.

Dengan adanya kegiatan ini, ibu hamil menjadi paham tentang pencegahan infeksi COVID-19 bagi ibu hamil, prosedur pemeriksaan kehamilan di era pandemi, cara menjaga kesehatan ibu hamil di era pandemi, upaya yang dilakukan ketika ibu hamil sakit di era pandemi. Peningkatan pengetahuan tersebut juga diharapkan ibu hamil tetap bersedia memeriksakan kehamilannya secara teratur untuk memantau pertumbuhan dan perkembangan janin dengan tetap memperhatikan protokol kesehatan. Hal tersebut sejalan dengan tujuan edukasi yaitu mengembangkan perilaku positif dalam rangka meningkatkan kesehatan (Maulana, 2009).

\section{KESIMPULAN}

Pemahaman ibu hamil tentang kebiasaan baru pada Ibu hamil dalam Pemeriksaan ANC dimasa Pandemi Covid-19 berguna untuk pencegahan infeksi COVID-19 bagi ibu hamil, prosedur pemeriksaan kehamilan di era pandemi, cara menjaga kesehatan ibu hamil di era pandemi, upaya yang dilakukan ketika ibu hamil sakit di era pandemi, yang kemudian menyadari untuk tetap memeriksakan kehamilannya selama pandemi COVID-19 dengan menerapkan protocol kesehatan agar pertumbuhan dan perkembangan janin dapat terpantau dengan baik.

\section{REFERENCES}

[1] Johns H. Bloomberg, 2020 .Covid-19 Communication Network, Synthesized Guidance for covid 19 Message Development, School Public Health

[2] Kemenkes, 2020, Kebiasaan Adaptasi Baru, http://promkes.kemkes.go.id/menuju-adaptasi-kebiasaanbaru, diakses 18 Oktober 2020

[3] Kemenkes RI. Situasi COVID-19. Kementerian Kesehatan RI. 2020 [Internet] (Dikutip Pada 20 Oktober) Https://Infeksiemerging.Kemkes.Go.Id

[4] Maulana, H. . D. J., 2009, Promosi Kesehatan. Jakarta: EGC.

[5] Notoatmodjo S. 2012. Promosi Kesehatan dan Perilaku Kesehatan. Jakarta: PT Rineka Cipta.

[6] WHO, Public Health Criteria to Adjust Public Health and Social measures in the Context of Covid-19, May 2020 
ISSN (Online) 2722-1083,

VOL 3 NO 1 OKTOBER 2021

Biodata Penulis I :

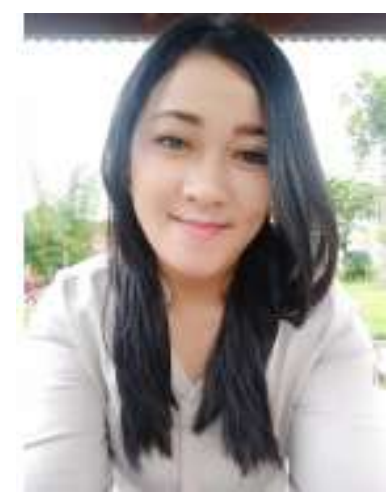

Riance Mardiana Ujung, SST,

M..K.M lahir tanggal 29 Agustus

1986 di Batang Beruh Kecamatan

Sidikalang Kabupaten Dairi, Putri

dari pasangan Herbin Ujung dan

Unur Siagian . Jenjang Pendidikan

tinggi Penulis dari D III Kebidanan

Poltekkes Kemenkes Medan lulus

Tahun 2008, D-IV Bidan Pendidik

Poltekkes Kemenkes Medan lulus

Tahun 2010, S2 Ilmu Kesehatan

Masyarakat Universitas Sumatera

Utara Minat Studi Administrasi dan Kebijakan Gizi Kesehatan lulus Tahun 2018. Penulis bekerja sebagai dosen tetap di Program Studi D III Kebidanan Tarutung Poltekkes Kemenkes Medan. Penulis aktif dalam kegiatan ilmiah dan dalam organisasi keprofesian.

Biodata Penulis II :

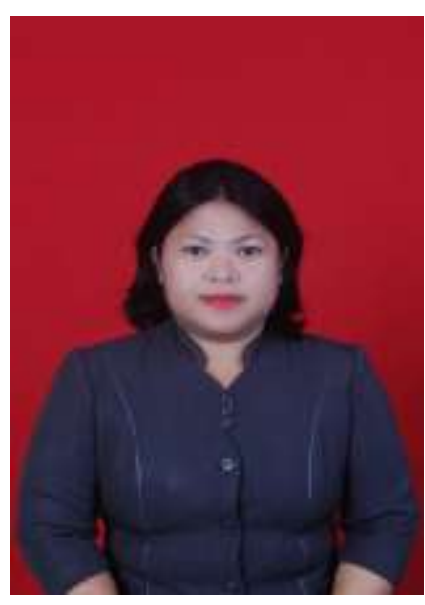

Dimpu Rismawaty Nainggolan, SST, M.Kes lahir tanggal 25 Oktober 1978 di Medan, dari pasangan B.Nainggolan (Alm) dan T.L.Hutapea (Alm). Pendidikan terakhir Penulis S2 Ilmu Kesehatan Masyarakat Universitas Sumatera Utara Minat Studi Kesehatan Reproduksi lulus Tahun 2015. Penulis bekerja sebagai dosen tetap di Program Studi D III Kebidanan Tarutung

Poltekkes Kemenkes Medan. Penulis aktif dalam kegiatan ilmiah dan dalam organisasi keprofesian. 